\title{
Haydn’s Oratorio “The Creation” Revival
}

\section{Triyono Bramantyo*}

Department of Music Education, Faculty of Performing Arts, Indonesia Institute of the Arts of Yogyakarta, Indonesia

\begin{abstract}
This paper has considered on analytical study surrounding Haydn's The Creation. It has discussed about the original of the libretto. It was started with Haydn's first summer in London, at the end of May 1791, when he witnessed the last of a series of festivals inaugurated in 1784 to commemorate the 25th anniversary of Handel's death, during which 'Israel in Egypt' and 'Messiah', among other works, were performed in Westminster Abbey by huge forces. The term revival, disparate as it was, always served some kind of distinct purpose, whether socioeconomic, educational, compositional, self-promotional, aesthetic, or political. Haydn's The Creation Revival means to show that Haydn's music might serve enough different purposes to evolve into a general critical revival.

In this study, it was found that each phase of the six days of creation that made up Part One and Part Two of the oratorio began similarly with a passage of biblical narrative sung by one of the three archangels, Gabriel, Uriel, and Raphael. The passages also contained of some materials of a lyrical or descriptive nature, amplifying the objective narration. These sections contained some of Haydn's most colorful music.

Most importantly, there was something inside of this magnificent oratorio of Haydn, despite of its structurally stand point. Something of countless of "most dramatic places" which could be understood toward a more satisfactory level of study, that was to say, through the aesthetics observation, because The Creation has so many symbolisms inside itself by which its meanings could not be appreciated only through the study of its formally plans.
\end{abstract}

Keywords: Oratorio; Structural Analysis; Revival

\section{Introduction}

In the event of Haydn's Oratorio 'The Creation' 217 years celebration this year, we would like to contribute the story of this oratorio revival from its early history to its present. In an introduction of Haydn's musical career written by Greenberg [1], it was described as follows:

"No composer did as much as Haydn to create and develop the Classical symphony and quartet and, to a lesser extent, other Classical genres, such as the trio and piano sonata. 'Papa' Haydn earned his nickname because of his good nature, the care he took of the musicians who worked in the orchestras he directed, and his sense of humor, which often found its way into his music."

The writer have excerpted the long story behind the success of Franz Joseph Haydn in this regard who was born in 1732 in the small town of Rohrau in Eastern Austria near the border with Hungary. In 1758 Haydn obtained his first permanent musical post to count Ferdinand Maximilian von Morzin. Early in 1761, count Morzin was forced to disband his orchestra through financial difficulties so that Haydn had look for another post. Prince Paul Anton Esterhàzy heard that Haydn was unemployed and at once offered him to the appointment of the assistant conductor of his orchestra at Einstadt, his palace near Vienna [2].

The story went on to Haydn's musical career in Vienna then as a kappelmeister (chapel master) and composer. An opportunity was given to him to visit London on 2 January 1791 and was much impressed by the vastness of London. In May 1791 a Handel festival was mounted in Westminster Abbey on a huge scale, with over a thousand singers and players. Haydn attended these concerts and the experience had an enormous effect upon him. After one performance of Messiah and of the 'Hallelujah' chorus in particular, he said of Handel, "he is the master of us all". It was as a direct result of this festival that Haydn began to consider of the possibility of composing an oratorio himself.

The dream came true when in April 1798, the first two performances of The Creation before a selected audience in the Palais Schwarzenberg in Vienna were announced. "Gesellschaft der Associerten" ("Society of Associates"), a group of music loving noblemen organized these two concerts. Haydn himself conducts the orchestra and the chorus with Antonio Salieri on the keyboard. Its success surpassed all expectations.

The success of The Creation was told by the critics of the Allgemeine Musikalische Zeitung who reported that: "it is difficult to imagine the silence and a attention with which the whole oratorio was listened to, only broken by quiet exclamations in the most dramatic places, and received with enthusiastic applause at the end of each piece and each section" [3].

The reasons why we restudied and revived this oratorio was in the one hand we saw the decline of Haydn reputation in the concert repertories whilst on the other hand we saw the potentialities of Haydn as someone who got the credit to the invention of the symphony, string quartet, and sonata form. Moreover, according to Tovey, d'Indy, Heinrich Schenker, Arnold Schoenberg, and Arturo Toscanini, Haydn barely scratches the surface of each of their life's work, and The Creation was as the example that might have provided the initial spark of the revival just by maintaining a nominal presence in the canon [4].

\section{The Libretto}

An attractive account concerning the search for the subject of Haydn's The Creation tells how during his stay in London his friend Salomon gave him a novel written by Milton entitled "The Paradise

*Corresponding author: Triyono Bramantyo, Department of Music Education, Faculty of Performing Arts, Indonesia Institute of the Arts of Yogyakarta, Indonesia, Tel: +628999025757; E-mail: t_bramantyo@yahoo.com

Received September 03, 2018; Accepted September 18, 2018; Published September 25, 2018

Citation: Bramantyo T (2018) Haydn's Oratorio "The Creation" Revival. Arts Socia Sci J 9: 407. doi: 10.4172/2151-6200.1000407

Copyright: () 2018 Bramantyo T. This is an open-access article distributed under the terms of the Creative Commons Attribution License, which permits unrestricted use, distribution, and reproduction in any medium, provided the original author and source are credited. 
Lost." The story of this novel was based on The Bible and Haydn, with the help of Baron Gottfried Van Swieten, the Prefect of the Imperial of Library in Vienna, had started to write a libretto for his first oratorio [5].

Meanwhile in another account Olleson impressively wrote that the earliest of the reports is found in a letter by van Swieten himself, which was printed in the Allgemeine Musikalische Zeitung in January 1799, and is the only one to come directly from someone (van Swieten) who had been immediately involved in the libretto.

Another account was written by G.A. Griesinger who had come to know Haydn well in his capacity as intermediary between Haydn and the Leipzig publishing house of Breitkopf and Härtel. According to Griesinger, the first idea of the oratorio The Creation, belongs to an Englishman by the name of Lidley, and Haydn was to compose Lidley's text for Salomon.

The third account, still according to Olleson, was the talk between Salomon and Haydn concerning the plan of writing The Creation. Salomon suggested him that since he had been successful in so many musical enterprises to date (a successes to which Haydn had contributed in no small measure) he became ever more venturesome for new undertakings.

Hence so forth, Haydn only remembered the English text when Baron van Swieten said to him, shortly after his arrival in Vienna; "Haydn, we are still waiting to hear another oratorio from you!" he told the Baron how things stood and showed him the English text. Swieten offered to prepare with a free translation of it in German, and once this was finished, it was wrong to think of that the oratorio was of Haydn's work that it had been written for London.

The writer saw structurally parts of the libretto that could be divided as follows: the first two parts of the oratorio one could see a consistent plan for the six days of Creation, and there were signs that the plan may had been still more consistent in the original libretto. Each act of The Creation was first stated in the words of the English Bible (the first chapter of Genesis, with one verse from the second account, Genesis 2: 7) and then provided with a free paraphrase and commentary. In the case of the Third, Fifth and Sixth Days, this procedure was followed in biblical style but not directly from the bible, introducing a song of general phrase by the heavenly host.

The writer confirmed that the first two parts were clearly articulated into the six Days of Creation. Each Day had its own internal organization, whereby it opened with a biblical narration, had a middle section of descriptive or lyrical commentary, and closed with a song of praise. The First Day ended up with descriptive chorus, rather than one of praise; a particularly demanding Day, such as the Sixth, which had to produce the entire animal kingdom freer, more lyrical passages. As befits the Seventh Day, the oratorio relaxed from the rigors of The Creation on Parts Three; here there was no biblical narrative, and the mood was entirely lyrical and idyllic.

The writer also found that the libretto of The Creation literarily could be divided into parts (teile) and scenes (auftritten). The indicated of the each part was shown in Table 1.

The arias including terzet (trio) of the three archangels and duet of Eve and Adam with their text sources can be described in Tables 2 and 3.

\section{Musical Sources}

Landon wrote that with the exception of Handel's Messiah, perhaps no oratorio was captured the imagination of the musical public as completely as Haydn's The Creation. Yet, whereas Händel's various revisions to accommodate the principle singers had been carefully documented by modern scholars, up to now it had been assumed that The Creation, as edited by Mandyczewski in the early 1920s for the old Breitkopf and Härtel collected edition (published in 1803), provided the definitive text (i.e. contains of van Swieten's word-books). H.C. Robbins Landon had clearly described that Breitkopf and Härtel issued the score in two versions, one with German and French texts, and another one with German and English [6,7].

\begin{tabular}{|c|c|c|}
\hline Indication & Translation & Movement \\
\hline Erster Teil & $1^{\text {st }}$ Part & $1-13$ \\
\hline Erster Auftritt & $1^{\text {st }}$ Scene & $1-2$ \\
\hline Zweiter Auftritt & $2^{\text {nd }}$ Scene & $3-4$ \\
\hline Dritter Auftritt & $3^{\text {rd }}$ Scene & $5-10$ \\
\hline Vierte Auftritt & $4^{\text {th }}$ Scene & $11-13$ \\
\hline Zweiter Teil & $2^{\text {nd }}$ Part & $14-28$ \\
\hline Erster Auftritt & $1^{\text {st }}$ Scene & $3^{\text {rd }}$ Day \\
\hline Zweiter Auftritt & $2^{\text {nd }}$ Scene & $14-18$ \\
\hline Dritte Teil & $3^{\text {rd }}$ Part & $19-28$ \\
\hline
\end{tabular}

Table 1: Indication of each part in the creation.

\begin{tabular}{|c|c|c|}
\hline Movement & Voice & Texts Sources \\
\hline 2 & Uriel & Paradise Lost VII: 236-242 \\
\hline 6 & Raphael & Paradise Lost VII: 285-287, 298-300, and 304-306 \\
\hline 8 & Gabriel & Paradise Lost VII: 315 \\
\hline 15 & Gabriel & Paradise Lost VII: 421 \\
\hline 22 & Terzet: Tree Archangles & Paradise Lost VII: 399-400, and 412 \\
\hline 24 & Raphael & Paradise Lost VII: $288-305$ \\
\hline 30 & Uriel & Psalm 104:27-30 \\
\hline 32 & Terzet: Three Archangels & Source unknown \\
\hline & Duet: Eve and Adam & Paradise Lost IV: $610-630$ \\
\hline
\end{tabular}

Table 2: Texts sources of the arias including trio (terzet) and duet. 


\begin{tabular}{|c|c|c|}
\hline Movement & Secco/Accompagnato & Source \\
\hline 3 & Combined & Genesis 1: 7 \\
\hline 5 & Secco & Genesis 1: 9-10 \\
\hline 7 & Secco & Genesis 1: 11 \\
\hline 11 & Secco & Source unknown \\
\hline 12 & Secco & Genesis I: 14 and 16b \\
\hline 14 & Accompagnato & Genesis I: 16-19 \\
\hline 16 & Accompagnato & Genesis I: 20 \\
\hline 17 & Combined & Genesis I: 21-22 \\
\hline 20 & Secco & Source unknown \\
\hline 21 & Secco & Genesis I: 24 \\
\hline 23 & Accompagnato & Genesis I: 25 \\
\hline 25 & Secco & Genesis I: 27 \\
\hline 29 & Secco & Genesis I: 31a \\
\hline 31 & Accompagnato & Source unknown \\
\hline 33 & Secco & Paradise Lost V: $17-31$ \\
\hline $3:$ & Secco & Paradise Lost IV: 774-5 \\
\hline
\end{tabular}

Table 3: Texts sources of the recitatives sung without accompaniment (secco) or with accompaniment (accompagnato).

However, the writer found the fact that as mentioned by authentic conductor named Brown, Mandyczewski's edition whose only source was the first edition published by Haydn (through Breitkopf and Härtel), had subsequently been the basic for nearly every modern performance. Ironically it seemed that Haydn never used this edition (Breitkopf and Härtel) for any of the performances with which he was directly involved. Indeed, like Händel, Haydn was constantly tinkering with the music, so that we could not speak, wrote Brown, of a definitive version.

The writer also studied into The Creation basic plans which were generally as one recitative followed by an aria, with the characteristic those instable tonal areas in the recitative followed by stable tonal center in the aria. Orchestration plan of The Creation was one of sparse instrumentation in the recitative followed by full instrumentation in the aria, with the two linked by common vocal forces. Not surprisingly, though, the text matches this plan. The recitative texts were generally from Genesis and were narratives. The aria texts were generally from Paradise Lost and were more reflective.

More importantly, the writer also found that the division between overture, arias, recitativo, secco, accompagnato, and chorus was very delicately balanced. The only duet was between Adam and Eve in Part Three, but the soloists often used with the chorus (e.g. Duet and Chorus No.30; also Part Three, the beautiful Terzetto No.27, which was really of larger structure and of course the famous conclusion to Part One, the Chorus No.13 “The Heavens are Telling”.

As for the general pictures of the tonalities used in almost the whole parts of this oratorio, it was certainly in the progressive tonality. The reasons for this elaboration of these tonalities seem to have been the concerned of the composer since as early as the introduction of Adam and Eve into the world of Angels, of God and Satan, and of the fallen angels.

\section{Part One}

\section{The overture}

Let now the writer begins to study the overture of The Creation that is open up by the orchestra and then concludes with the recitative of Raphael at bar 60, "Im Anfange schuf Gott" ("In the beginning God Created"), Chorus "Und eine neue welt" ("A New Created World"). The Overture is entitled "Die Vorstellung des Chaos" ("Representation of Chaos").
Look into this Overture or Einleitung closely, it can be noted that it is the whole work of symbolism without words: it is, in a sense, up to the listener to make up his own programme when listening to what is officially called "Die Vorstellung des Chaos". The clue to appreciate this symbolism perhaps can be started over with the question of how the Chaos can be represented without words?

In answering the question, however, let the writer refers to Charles Rosen, who in his book entitled The Classical Style, wrote exactly almost the same enquiries: "By what chaos is represented, and how can Haydn's musical language express and this and still remain language? The answer by Rosen was, Simply by the absence of clear articulation in large phrase-groups, which merge and blend with each other and by the clear at definite cadences $[8,9]$."

Meanwhile, suggesting about this, Sir Francis Donald Tovey, in his Essays in "Musical Analysis", described that it is the isolation of the musical event which creates the chaos. "In other words, they are admirably chaotic: they are not nonsensical, for their resolution is quite orthodox, though they occur as shocks for which their antecedents did not prepare us [10]."

Different views should also be added here that according to Landon, The Creation text is full of symbolism; it is also full of descriptions which automatically suggest Tonmalerei (tone painting), or realization of this descriptions. Throughout the Creation, Haydn explored symbolism in two forms; first, tonality and, second, the use of instruments to express a concept [7]. It seems that in this Overture, in order to describe this symbolism, it is found that when Raphael enters as the first human voice after the description of "Chaos", Haydn describes the beginning of the world as we know it from Genesis I: 1-2; "In the beginning God created the heaven and the earth. And the earth was without form, and void: and darkness was upon the face of deep."

\section{Aria (Uriel) with chorus}

Now when the writer looks into the whole arias in The Creation, generally, all of the movements are unified by their metric flows and musical contents. In movement No. 2, for instance, the differences between sections is delineated by their non-idiomatically related tonalities, contrasting texts, moods, texture, and orchestrationapproach to the extreme of the accompanied recitatives.

Technically No. 2 is an aria with chorus in a complex and symbolic key relationship of A major - c minor - A major. This symmetric concept of structure is typical form of eighteenth century concept of symbolism and it was worked well in Haydn's The Creation. The content of the text according to Landon is "The shadows of night flee to the deep of abyss, to endless night", from A major downs to $\mathrm{c}$ minor and when A major reappears 'A New Created World springs up at God's command [7].

\section{Recitative (Raphael)}

What can be described about this recitative is as the first recitative in which there is only a line at first, mostly configured later this number changes an accompanying. This is the first of the famous descriptive recitative in which the music describes some aspect of the universe; these sections are so constructed that the music comes first, the words afterwards. Here we have (1) "outrageous storm"; (2) "as chaff by the winds are impelled the clouds"; (3) "lightning"; (4) "thunder"; (5) "showers of rain"; (6) "wasteful hail"; (7) "the light and flaky snow" - all portrayed with relish and a great sense of instrumental color. 


\section{Chorus with Soprano Solo (Gabriel)}

For the writer, it is very impressive to find out of how the Archangel Gabriel appears for the first time in this Solo in a stunning Allegro with oboe obbligato. The chorus comes in at measure $16(\mathrm{~m} .16)$. The violin's rhythm is doubled by the timpani (m. 16) and by an oboe arpeggio. Structurally, file layout seems to be like one huge ritornello: solo oboe (mm. 1-4), solo soprano (mm. 4-16), then comes the chorus in Handelian manner (mm. 16-30), and then the chorus and solo soprano (mm. 31-46) recalling the first theme but is now progressing to a stupendous passage where the soprano soars above the chorus and orchestra to a high c"' (m. 44) with only the first flute is in the same range. No.4 rounds out the first $\mathrm{C}$ major cycle of the Oratorio; the key that will not return until the end of the Part One.

\section{Recitative (Raphael)}

What can be described about this recitative is that this is a secco recitative which leads to the first aria. The text is Genesis I: 9-10. The melodic content of the beginning and ending of this recitative is very similar to that of the other recitatives. Each of the melodic cadence which conclude the two sentences of Movement 5 ends in a descending perfect fourth. This is similar to the final cadences in all of the secco recitatives except Movement 9,11 and 20. It should be noted here that while this may not have been a conscious linking on Haydn's part, it, along with the overall syllabic declamation, harmonic language, tonal instability, and Spartan orchestration, does add unity to the secco recitatives in The Creation [11].

\section{Recitative (Gabriel), and Aria (Gabriel)}

The writer should specifically notes that this beautiful Aria entitled "Nun bout die Flur das frische Grün" ("With verdure clad the fields appear") in B flat, is probably the most famous single aria in The Creation. In its simplicity of melody, its elegant off-the beat phrasing and its limpid orchestration (no oboes: only flutes, solo clarinet, bassoons, and B flat alto horns), it has become a touchstone for the Viennesse Classical Style in vocal writing. There is just enough coloratura to enable the soprano soloist to display her agility, but never too much.

\section{Recitative (uriel) and chorus}

In order to study this recitative and chorus, the writer should mention that according to Landon's opinion that if there is any part of the oratorio which suggests a direct comparison with Handel, this chorus is surely it; partly because it is in Handel's characteristic trumpet key of $\mathrm{D}$, partly because we have fugue in the middle. But furthermore, Landon wrote, we must recall that this is modernized Handel, with the orchestration of the Mozartized Messiah and with the restricted trumpets restricted (as they were in Mozart's much criticized adaption). One wonders if Haydn would not re-orchestrated Handel more fittingly than Mozart, to whom this style was basically foreign: we mean not, of course, the Baroque but, rather the oratorio. Mozart was certainly the most universal genius in the history of music, but oratorio writing did not slit him at all [7]

\section{Recitative (Uriel), and recitative accompagnato (Uriel)}

A Secco leads into the justly celebrated first sunrise, the first moonrise, and the sons of God, gathering together and shouting for joy - and leading without pause or even cadential resolution into No.13, the Chorus with the Three Archangels Soli [7].

However, Brown described that the sunrise of the No. 12 also have precedent in French pictorialism, as does the high flute colour of No. 27, which suggests both pastoral bliss and the celestial world on earth [8]. He also added that Haydn's most densely pictorial music is concentrated in three extended accompanied recitatives for solo voice (No. 4, 13, 21), which must have delighted every liebhaber (lover).

\section{Chorus (with the three archangels)}

It was so impressive to look over this chorus that according to Landon, is the most famous chorus In The Creation and for many years Haydn's most played choral piece altogether, "The heaven are telling" sums up the first art in a glorious outpouring of $\mathrm{C}$ major [7].

\section{Part Two}

\section{Recitative, and Aria (Gabriel)}

As the sketches show, Haydn always intended: this to be a bravura (florid passage requiring great skill and spirit) piece. The writer should mentioned when Landon referring Tovey's statement that though the accompanied recitative starts on the six chord of $\mathrm{C}$ major, as if to continue a narrative that has been punctuated rather than interrupted, the ritornello of the Aria is so long ( 34 bars) that it was obviously made to serve as two introduction to Part Two. As in the previous soprano aria, the oboes are dropped and the clarinets have a prominent part [10].

\section{Recitative (Raphael)}

It is very impressive recitative and a good example of great description of life multiplying with the divided lower strings. Here the divided violas and divided cellos with the double bass in its lowest register, together the key of $\mathrm{D}$ minor, create a mysterious, veiled sound - as mysterious as the secret of life itself. The whole passage remains piano and the complexities of the divine spark of life are mirrored in the intricate, almost Bachian lines of the stringed instruments.

Brown impressed us with his statement; "next to the appearance of light, perhaps the most impressive of these accompanied recitatives is Raphael's "Be fruitful all, and multiply!" (No. 16) [8]. It again can be admired by the amateur sensuous orchestration of the lower strings and declamatory, majesty, and by the connoisseur for its impressive part writing."

\section{Recitative (Raphael, and Terzetto, leading to chorus with Soli.}

A very short Secco, wrote Landon, leads to the A major Terzetto, scored with the characteristic delicacy that Haydn always reserves for this key (flutes, oboes, bassoons, horns, strings) [7]. The words are first given to Gabriel, who sings of the "sloping hills" and the "crystal drops" of the fountains. Uriel then describes "the cheerfully host of birds with their wings shining in the sun", and Raphael follows with "the fish in the ocean and the immense leviathan (who) sports on the foaming wave".

\section{Recitative (Raphael) and recitative (Raphael)}

Here we found another short secco, leads to what is probably the most famous of the descriptive accompanied recitatives. The tawny lion is portrayed, "cheerful roaring" with $f f$ trombones and double bassoon, followed by the "flexible tyger" (sic) and the "nimble stag". For the stag's music, we move to the hunting metronome of six-eight but, more surprising, the music is a quotation from the recapitulation of the "Surprise" Symphony's first movement bars 207ff. There then follows the horse with "flying mane and fiery look" and the bucolic scene (pictorial poem) with "fleecy, meek and bleating flock", and 
finally the famous imitation of the worm creeping "in long dimension". The final bass note of the recitative, 'd', is usually put down an octave here, a liberty of which Haydn would certainly have approached.

\section{Aria (Raphael)}

This is another famous aria of this oratorio. Here Raphael sings of heaven's glory "Nun scheint in pollen Glanze" ("Now heaven is fullest glory shone") with stiff horns, trumpet and timpani fanfares the basic rhythm of which colours much of this music. Beneath the bass solo's words "den Boden drückt der Tiere Last" ("By heavy beasts the ground is trod"), suddenly growls out the famous bassoon and double bassoon passage.

Recitative (Uriel) and Aria (Uriel): Genesis I:27 described that "God created a man in his own image ... He breathed into his nostrils the breath of life, and man became a living soul". This is the text of this secco recitative which is lead to the Aria in C major "Mit Würd und Hoheit an getan" ("In native worth and honors clad").

About this magnificent Aria, Landon gave us his impression that if one had to choose the greatest single Aria in The Creation, it would probably fall in this majestic, poetic and original piece. Its freedom of form, wrote he, is extraordinary and has been much admired. Landon quoted Tovey's comment who had described that "we have not only the quintessence of Haydn but the perfection of bel canto [10]."

The formal shape of the text of this number is filled into two distinct sections. The trumpets and the timpani leave the orchestra (m. 54) as soon as Haydn described man, and a beautiful obbligato violoncello part emerge (m. 55) and dominates the texture to the very end. To illustrate "the breath and image", Haydn introduces a fantastic modulation to the flattened submediant $\mathrm{Ab}$ (mm. 48-51). The second part is a song to 'love and joy and bliss' which dies away in pianissimo (mm. 55-10l).

Brown described that this Aria moves from activity to relaxation. It becomes martial with dotted rhythms as man is declared 'the lord and king of nature all', but the music for the concluding three lines of text provides tonal stability, rhythmic relaxation, regularity of phrasing, and a new counter-melody in the cellos that anticipates the later duet of Adam and Eve [8].

Recitative (Raphael), chorus, Terzetto, and chorus: In analyzing these numbers, we found that after an eight-bar secco, we begin the mighty "Finale" with which Haydn concludes the Second Part of The Creation. No. 26 is a shortened version, with different fugato of No. 28, but the final ritornello of No. 26 ( $\mathrm{mm}$. 33-37) cleverly introduces material from which the great double fugue in No. 28 (mm. 10-68) will be formed.

About No. 27 which has a striking projection of word to music, Haydn uses several methods to treat the words symbolically: (a) he breaks the flow of the music by suddenly switching to triplets; (b) he leads the bass solo (Raphael) to the bottom register; (c) he takes us to $\mathrm{Gb}$ major (home key: $\mathrm{Eb}$ ). In the English version the low $\mathrm{Gb}$ of the Archangel coincides with the word "dust"; in German it is equally effective, coming earlier but on the note $\mathrm{Cb}$. Notice, too, wrote Landon (1970), how Haydn prepares the words "Du wendest". Up to this point the orchestra has consisted of wind instruments only (flute, oboe, clarinets, bassoons and horns) with Gabriel and Uriel. They finish their cadence at bars 33ff, then the music "turns away" (a) from the wind band. (b) from the major and (c) from the soprano and tenor soli.

In the final part of this solemnly beautiful trio Haydn depicts "now force and now delights" with a motive which rise up an octave in all three voices, starting with Archangel Raphael (mm.85-89).

\section{Part Three}

\section{Recitative (Uriel)}

Looking closer to this recitative, there are three flutes used here symbolize "the morning young and fair" and "still innocent Adam and Eve". In the first section, or until the recapitulation of the opening material, only flutes, horns, and strings are used. Measures 29-32 present us with the repetition of the beginning but in its original state, ie., just the three flutes unaccompanied. These unaccompanied flutes were to open No. 29, but Haydn later added the pizzicato strings. After the flute have repeated the opening material, they are silent. Similarly, the horns have a short solo section (mm. 39-40) and are the removed, making way for bassoons and oboes. By the time we have modulated from $\mathrm{E}$ to G, we can see, No. 29 for that which it really is, namely a fast slow introduction to No. 30 .

\section{Duet and chorus (Adam and Eve)}

This movement is in the very slow build-up. First a fine oboe singly emerges from the strings triplet, then Adam and Eve begin their song of thanksgiving. It is not until measure 24 that Haydn adds more woodwind (flutes, oboes, bassoons). At the end of that measure the chorus, comes in, almost chanting. At measure 31 the extraordinary timpani solo begins and continues all through this Adagio. This entire No. 30 is unique in late period Haydn. The case with which the key structure planned is as admirable as the invention and inspiration with which the whole piece is informed.

\section{Recitative (Adam-Eve) and Duetto (Eve-Adam)}

We need the widest possibilities of contrast after nearly four hundreds measures of No. 30, and Baron van Swieten provided Haydn with the simplest method, ie., a long secco recitative of Adam and Eve. It can be noted that the $\mathrm{Bb}$ chorus ending Part Two could also be regarded as the dominant key of the forth coming Eb Duet. To underline this relationship, Haydn has recourse to a clever device.

\section{Conclusion}

We would like to point out that from this analysis study we could find out that Haydn put into the immense work of his Creation the compositional experience of a lifetime: the technique of thematic work came from the symphony (he wrote as much as 108 symphonies in Grove's Dictionary 1980 list), the detailed knowledge of character and sound effect of individual instruments betrays the composer of chamber music, the melodic diversity and seemingly natural relationship between words and music, the writer of operas and songs. In the powerful fugues and double fugues of the choruses, the organist and master of counterpoint demonstrate his skills. But in the tone paintings of storm and rain, birds and fishes, sea and mountains, it is imaginatively serene artist. The end result of this collaboration is an oratorio which denotes both a temporary climax in, and an end to the development of the style.

Finally it should be wise to cite Hogwood's impression which is quite impressed us, describing that "The Creation is more than a work for musical amateurs and connoisseurs, conservatives and progressives, and more than a variety of national tastes: it is as two centuries have verified, an oratorio of all time [12]." 


\section{References}

1. Greenberg R (2000) Haydn: His Life and Music. California, CA: The Teaching Company.

2. Butterworth N (1984) Haydn in the series of the Illustrated Lives of the Great Composers, London: Omnibus Press.

3. Kluge A (1992) Choral Works in the Spirit of the Enlightenment, Haydn's Creation, a program note to a Sony Classical CD, The Royal.

4. Proksch B (2015) Reviving Haydn: New Appreciations in the Twentieth First Century. Rochester, NY: University of Rochester Press.

5. Olleson E (1968) The origin and Libretto of Haydn's Creation, in Haydn Yearbook No. 4.

6. Griessinger GA (1965) Correspondence with Breitkopf \& Hartel, In Haydn Yearbook No. 3.
7. Landon HCR (1970) Haydn's Creation, Essays on The Viennese Classical Style. London: Creset Press.

8. Brown Peter A (1989) Haydn's Chaos: Genesis and Genre in the Musical Quarterly No.73

9. Rosen C (1972) The Classical Style. New York, NY: WW Norton

10. Tovey DF (1939) Essays in Musical Analysis, New York, NY: Oxford University Press.

11. Lucas JA (1977) A Conductor's Analysis of The Creations by Joseph Haydn lowa: The University of lowa, DMA Dissertation.

12. Hogwood C, Luckett R (1983) Nicholas Temperley New Light on the Libretto of the Creation. In Music in Eighteenth-Century England: Essays in Memory of Charles Cudworth, New York, NY: Cambridge University Press. 